Aleksey ZAGREBIN (Izhevsk)

\title{
Some aspects of modernization in Udmurt rural society
}

\section{The meaning of modernization in the Volga area}

The phenomenon of modernization is understood as a complex of interconnected transformational processes which form the modern world. The scientific concepts of modernization emphasize that it has many ways of development in traditional societies. At the same time, researchers of modernization processes often overlook the ethno-cultural features relating to certain people, mainly because they believe that values are universal and 'westernization' is a good thing. It was discovered recently that direct copying of suggested models was inconsistent, which makes us give further interpretation to the theory and practice of modernization, especially locally.

In the last decade there has been a rise in regional historical and cultural studies of societies in which modernization has had an accelerated, 'catching up' form and has very often been initiated by more dynamic neighbors. Local people have had to adopt new life standards and expand their knowledge about the environment in a short space of time. It is very interesting to study the early stages of joining the present by such societies, which were taking place mainly at the end of the 19th century and the beginning of the 20th. In that period, correlation of traditions and innovations did not become critical, with the second being superior to the first; this was challenging for a people but was not a matter of its survival. It was because all innovation projects at that time were bold and pragmatic, but they were evolutionary rather then revolutionary and were not opposed to tradition. It is also interesting to study the unrealized hidden potential of initial modernization and how our peasant ancestors changed their style of life.

In a monograph by Igor K. Kalinin (2000), there is an original sociophilosophical conception of 'a three-stage modernization' of Komi, Mordva, Mari and Udmurt, which started at the end of the 19th century and the beginning of the 20th and continued during the post-Soviet period. The author follows Max Weber's scientific paradigm, giving a thorough study to changes in public consciousness in those societies and how they were connected to the social environment (Kalinin 2000: 7-12). As for periodization and chronology, it seems questionable to consider 1917 as a key year, because to Russian peasant communities it felt little different to other hard years. A new turn of social, cultural and technological innovations was not really recognized by them until 
the collectivization period, and research on dynamic processes in economics partly confirmed it.

For example, in his book "Economic dynamics issues" Nikolay D. Kondrat'yev wrote that in the circle of 'a long economic wave' lasting for 48-55 years there are recessions accompanied by a long economic depression in agriculture (Kondrat'yev 1989: 199-208). During economic recessions there is always a search for ways of reducing production costs, and demand for innovative ideas increases. Cumulating innovations become one of the conditions for destroying an old system and the concurrent growth of a new order. Studying those wave processes allowed the discovery of the following regularity - the highest innovation peaks occurred in the 1880s and 1920s, which were periods of economic recession. In those periods new communication channels were opened locally to transmit innovative ideas.

A communicative approach to the research on ethno-cultural dynamics is applied in a monograph by Aleksey G. Krasil'nikov (1999). The author shows changes in the worldview of people in a Udmurt rural community, where in the last quarter of the 19th century literacy was valued as very useful, giving more freedom and personal independence. A similar point of view can be found in the works on innovation diffusion by American researchers Everett M. Rogers and Floyd F. Shoemaker. They noted that the communication chain, which works as a mediator, consists of four main elements: source - signal - channel - receiver (Rogers \& Shoemaker 1971: 102). Therefore, progress in modernization very much depends on how well developed this communication chain is and on its ability to store and transmit information, as well as to adopt innovations.

No less important is the role of innovation 'receivers' and their attitude to the influence of outside forces. The traditional scale of values cannot sustain the pressure of new impulses, if may be characterized as 'a cultural shock'. American researchers Adrian Furnham and Stephen Bochner determine 'cultural shock' as resulting from something new, when experience brought by a new culture seems unpleasant or shocking because people are not ready for it and because it often leads to negative evaluation of their own culture (Furnham \& Bochner 1986). In his book "Interethnic relations in Udmurtia. Historical and psychological analysis", the Udmurtian researcher Georgiy K. Shklyayev says:

When the environment changes, a people has to rebuild its structure, use extra ethnic means to keep, reproduce and develop its ethno-cultural information network and transmit it via this network. (Shklyayev 1998: 203.)

In such circumstances a people tends to isolate itself by building protective barriers to prevent 'dangerous innovations' from penetration. Another side of cultural shock is that for some individuals this unexpected break in the life paradigm stimulates their active self-development, especially leadership, responsibility and enterprise. At the same time, the unity of the peasant world, which 
remains unbroken for a long time, gives the necessary social support and helps most of the people endure discomfort.

Before presenting the material on Udmurt rural society history, I would like to say that the 50 years that we are going to talk about are not only the beginning of modernization, but also a time of giving up the past, and this giving up was not recognized by everyone. In order to illustrate the problem better and in a more concrete way, we can turn to the cognitive capabilities of the microhistorical approach to empirical material analysis. Although in modern ethnology there is well-reasoned criticizing of studying 'typical towns and villages' as abstract models, even the most rigorous critics do not deny that such works allow us to see 'something significant' in those local worlds.

\section{Udmurt and Russian relations: historical background}

The relationships of Udmurts in ethnically diverse communities was considered by Galina A. Nikitina (1993). The author discovered that the main contradiction occurring in such social communities was the following:

Being originally from communities where social stratification was more profound, Russians brought individualistic inclinations into the Udmurt buskiel (neighborhood), whereas Udmurt peasants still remained devoted to community traditions, and private ownership was not so well developed there. (Nikitina 1993: 29.)

Facing a new situation, the council of Udmurt farm owners, kenesh, had to look for solutions to all the vexed questions which arose. The first of the possible ways of reducing the influence of new settlers on the internal order of the life of the community was to secure all the main means of production for themselves. Initially, the Udmurt peasants let Russian settlers use nearby grassland, because they considered it their own 'serf' land. But gradually and on various pretexts the best lands were secured for the richest Udmurt and Russian families, whose heads were important at local meetings. Therefore, even by building those barriers the Udmurt community was becoming involved in the new system of relationships.

As for the way of life, the only problem for the new settlers was a discrepancy between their own high self-esteem compared with the local people and, on the other hand, their economic instability, at least in the beginning. For this reason, these migrants tried to settle next to each other forming so-called 'Russian corners' or 'Russian ends', and also developed crafts which did not require a lot of manpower and land.

Another way of segregation was that the Udmurts who did not want to live in the same community as the new settlers moved to the neighboring Udmurt villages. In their turn, the Russians who did not like the rules in the local Ud- 
murt community moved to other settlements or started their own purely Russian ones.

Internal community relations were also dramatic. In many local communities there were groups of so-called koshtani (hooligans), which consisted of Russian settlers who were called zevlasti (bold and assertive) men. They determined whether a new settler was accepted into their community, or who could rent a mill or market. Anyone who needed the local meeting to take some favorable decision had first to arrange it with the koshtani and bribe them with a few buckets of vodka. Anyone who dared to protest against this tyranny was beaten up or dealt with in some other way. For example, the peasants who dared to resist pressure were getting the worst land, which was divided into land strips far from each other and from the village.

The way out of this crisis was found through people's common sense. It was decided to redistribute land only once in twelve years. Obligatory communal works were now done by voluntary artel-streets or desyatok (a group of five to ten families). Therefore, each house owner now cooperated with the people he wanted to, Russians with Russians, Udmurts with Udmurts, and most of the time people were from one family. In the course of time, people adjusted to each other, their common troubles and hopes smoothed out ethnic stereotypes. It was especially distinct in the second generation of new settlers who were either born in the village or brought there when very young. They adjusted to their new environment, many of them learned the Udmurt language from their Udmurt friends, and on the whole Udmurt culture was not such a mystery any more. Joint local feasts, recruitment, inter-marriage and bilingualism let us presume that by the time of collectivization (which split the rural community again), the peasants were a more or less united community.

The main thing in a peasant's life was no doubt food production, which determined everything in rural economics. It is believed that capitalist relations, which developed much earlier in modernized cities, made peasants' production activities change and reorient their households to the market model. But this was possible only where developed and steady capitalism was the social and economic system. Udmurt rural society was only taking the first steps in this direction. Besides that, the effectiveness of labor in the countryside depended directly on how available the main means of production were, i.e. land and manpower. The latter was especially important because of the lack of agricultural equipment.

The foundation of the social structure of rural society was the family, where everyone had his or her role functions, which had been established for centuries. But at extremely busy times, such as haymaking or harvesting, more complex teams were formed. That is, the above mentioned artels or desyatok which were made voluntarily by community members. On the appointed day a party of 10 to 15 carts came to the grassland of such a desyatok carrying peasants, all the 
necessary tools and a lot of food. All the family members came out to work in the fields, leaving only disabled elders, the sick and the younger children at home. They set up camp in some convenient location, put up tents and started work. They worked and ate together and divided the proceeds by the number of people registered by population census and assigned to this grassland plot.

The production process was managed by the householders, who represented their family at village meetings. They were responsible for the wellbeing of the family. But although they were a significant authority in the family, their power was not despotic. The head's wife, who was called kuzyokishno, traditionally had a higher social status, which was based on her dowry. In many families there was a rule that a wife had her own money separate from her husband's and she earned it by selling needlework, milk and eggs. Having her own money sometimes allowed a woman to decide their children's future. There were cases where mothers not fathers made their sons go and study in educational institutions in Elabuga, Kazan, Vyatka or Kukarka, whereas the fathers encouraged their children to work in the fields or do craftwork without expanding those limits.

It should be said that for most of the people the environment was not limited to their own village, but was clearly divided into real and abstract worlds.

The real world, which was familiar since childhood, included their home, their village, its nearer and farther outskirts, the neighbors and people from the surroundings who came to church, the local district government and the services in their vorshud (religious organization). The boundary points of the real world were the two nearest district towns. They were situated about 100 versts (1 Russian verst $=1069 \mathrm{~m}$ ) from the village; however they formed one communicative vector, which had constant road communication and a regular mail service. Being familiar with the real world, which continued all their life, made people self-confident even when visiting other towns and cities.

The abstract world used to be a kind of fairy tale fantasy combining people's ideas about the state and a far-away country with biblical stories and pantheism. Over the course of time it was gaining more distinct forms and images. The stories told by a schoolteacher pointing at a map of the world or by an elder brother who had come back from the army. Smallpox vaccination was undermining traditional barriers. Fresh newspapers and magazines were often used in unusual ways. For example, people papered the walls in their houses with newspapers, or decorated a bride's chest with press cuttings from a fashionable Niva magazine.

The shock experienced by Udmurt rural society from having to deal with non-standard situations also had a positive impact. It raised people's responsibility for decisions taken both individually and collectively. A stress factor that was ruining the former stability, was the constant arrival of Russian peasant settlers who had new skills, know-how and a different worldview. Their innova- 
tive potential could not be underestimated, but inequality in social status and an inclination to conflict reduced their role as innovation agents. Many researchers noted that "Votyak (Udmurt) was very cautious in adopting innovations especially if they came from Russians". In such cases, state bodies, which were responsible for the translation of innovation ideas, became very important. Zemskiye institutions, which were established at the end of the 19th century and the beginning of the 20th and were responsible for economic and social development locally and by the locals, became a very important channel for introducing useful innovations.

The education system and school in particular were at all times agencies which introduced rational knowledge. School teachers who worked in the countryside in those days deserve special study, because they bore the characteristics of Russian intelligentsia with its selfless devotion and even a kind of messianism in serving the common people, and at the same time being distant from them and treating them as small children. Among rural schoolteachers there were many who were originally from the clergy and even peasant classes, but there were also people from the upper classes. Local people considered schoolteachers as almost supernatural people who knew a lot and at the same time did not understand very simple things.

Modern modes of treatment, hygiene and disease preventive measures were applied by local medical centres. There were more Russians among their patients, which could probably be explained by the Udmurts' devotion to home treatment and a well-developed network of witch doctors.

\section{Innovations in Udmurt villages}

Coming back to the main topic, it is worth noting that innovations were varied and adopted mainly in relation to how practical and necessary they were and how prestigious it was to use them. The fact that people used them, especially those who were well known by everyone in a village, was their best form of promotion. Oil lamps, aniline dye, ready-made clothes, photography and many other things which became the attributes of the new times, were first used by people who were called the rural intelligentsia.

Speaking about the innovation potential of the intelligentsia, we should not forget about those who were the first to meet the Udmurt peasants, i.e. the orthodox clergy. Introducing state policy, they influenced their congregation through parish schools, charitable institutions and seminaries. Many of the clergy could speak Udmurt, which was necessary for making their missionary work effective.

When speaking about modernization in rural societies, it is important to mention leaders whose competent opinion determined the speed and the social and economic orientation of those changes. In my opinion, there was a special 
innovation complex in that period, which consisted of people who were personally interested in its success. Invisible links went through vertically organized society, which was going through four stages: knowledge - belief - decision adoption. Knowledge was coming from leaders and went back to them. But firstly they were outstanding people from the upper social classes who had power, whereas the leaders who adopted innovations remained members of their community and kept to its traditional values, although inside they were ready to come out and lead, reflect and translate. The general rule was that, first, cultural borrowings, which were strange to the ethnic tradition, penetrated into the everyday life of the upper classes, and then they filtered downwards establishing links with traditional culture.

As a preliminary conclusion we can presume that local people's culture was influenced through two innovation channels. On one side, it was Russian peasant newcomers, and on the other, the state structures. Modernization projects, which did not have any national message and were started by the state in the end, were more successful. Because of that, the most open-minded people realized that their traditional culture was valuable but not sufficient on its own. Many of them did a lot of inside work to abandon the ethnic, cognize the international and finally recognize the national. However, we have to admit that their future was rather unhappy. The next stage of soviet modernization set other goals and the initial project of modernization remained unfinished.

\section{References}

Furnham, Adrian \& Bochner, Stephen 1986: Culture shock: psychological reactions to unfamiliar environments. London - New York.

Kalinin = Калинин, И. К. 2000: Восточно-финские народы в процессе модернизации. Москва.

Kondrat'yev = Кондратьев, Н. Д. 1989: Проблемы экономической динамики. Москва.

Krasil'nikov = Красильников, А. Г. 1999: Духовная культура этноса: от устной к письменной традиции (на материалах восточно-финских народов). Ижевск.

Nikitina = Никитина, Г. А. 1993: Сельская община бускель в пореформенный период (1861-1900 г2.). Ижевск.

Shklyayev = Шкляев, Г. К. 1998: Межэтнические отномения в Удмуртии. Oпыт историко-психологического анализа. Ижевск.

Алексей Загребин <zagreb72@izh.com>

Удмуртский институт истории, языка и литературы УрО РАН

Россия

426004, Удмуртская Республика

г. Ижевск

ул. Ломоносова, д. 4 